\title{
Variability and Mutual Coordination of Models of Economic Behavior of Enterprises in Digital Space
}

\author{
N.P. Karachyna, M.O. Samofalova, Y.V. Bilyak, N.I. Drahnieva
}

\begin{abstract}
Interpretation of "model of economic behavior of the enterprise" category is formed. The variability of modern models of economic behavior of enterprises in the context of the relevant criteria of generalization: the strategy of activity, the mechanism of adaptation to market conditions, transformation of economic conditions and readiness for adaptation. The mutual coordination of certain models of economic behavior of enterprises is established and characterized. The author's position on the types of models of economic behavior of enterprises: production-oriented, rent-oriented and mixed is justified. In applied aspect (on the basis of 13 enterprises) modeling of economic behavior of enterprises in interrelation with the expressed variability of models of economic behavior of the enterprises is carried out in digital space.
\end{abstract}

Keywords : economic behavior, model, model of economic behavior of enterprises, production-oriented behavior, rent-oriented behavior, mixed behavior.

\section{INTRODUCTION}

Problems accumulated during the evolution of economic foundations of modern civilization, as well as the recent growth of the role of uncertainty factors and instability of economic environment indicate the actualization of task of searching for conceptual options for the effective development of modern enterprise. In general, the problem, as we believe, is to exhaust the possibilities of common approaches until recently and relevant categories to ensure adequate identification of the state, cause-and-effect mechanisms and prospects of transformation of the enterprise as the basis and the primary chain of the socio-economic basis of society.

The basis of the author's idea of an alternative methodological basis for such analysis is the statement about the prospects and deeper, compared with traditional approaches, scientific objectivity of the analysis of the enterprise concept on the basis of a comprehensive study of principles of its behavior.

While realizing this behavior as a complex combination of

Revised Version Manuscript Received on October 15, 2019.

N.P. Karachyna, Marketing and Economics Department, Vinnytsia National Technical University, Vinnytsia, Ukraine. (Email: karachyna.n@gmail.com)

M.O. Samofalova, associate Professor of I.S. Zavadsky Management Department, National University of Life and Environmental Sciences of Ukraine, Kiev, Ukraine. ( Email: marija.samofalova@gmail.com)

Y.V. Bilyak, Financial Department, National University of Life and Environmental Sciences of Ukraine, Kiev, Ukraine. (Email: gogoniyaV@gmail.com)

N.I. Drahnieva, associate Professor of I.S. Zavadsky Management Department, National University of Life and Environmental Sciences of Ukraine, Kiev, Ukraine. (Email: nidragneva@gmail.com) socio-economic factors, identified as a separate independent unit of our analysis studies of the economic behavior of enterprises and their models that somehow can be considered a reflection of the total direct or indirect influence of all other factors. Therefore, "model of economic behavior of the enterprise" category is considered as the leading to explain the principles of the enterprise functioning.

Problems of determining the essence of economic behavior concern the research of many well-known foreign academic economists. In particular, A. Smith, P. Heine, A. Marshall, F. Hayek, K. Marx, M. Weber, H. Schmoller, T. Veblen, W. Mitchell, J. Commons, R. Coase, J. Buchanan, G. Simon, D. North, J. Schumpeter W. Sombart. A significant contribution to the definition of the etymology of economic behavior of enterprises have made such modern domestic scientists, as $\mathrm{N}$. Shybaeva, G. Kaplenko, M. Gurevychov, V. Woitko, A. Azrylian, O. Miklukha, N. Biloshkurska. At the same time, the applied aspects of assessing the economic behavior of enterprises, the formation of economic behavior of enterprises models and their relationship are insufficiently developed.

The object of the article is to determine the existing models of economic behavior of enterprises, the disclosure of their essential content, the separation of the author's position on the modeling of economic behavior of enterprises and the establishment of mutual agreement between them in the plane of theoretical and applied research.

\section{PRESENTATION OF THE MAIN RESEARCH MATERIAL WITH FULL JUSTIFICATION OF SCIENTIFIC RESULTS}

Exploring the evolution of the essence of economic behavior and revealing its motivating factors, repeatedly focused on certain behavior models. However, this was observed only through the spectrum of scientific results as a priori. We consider it necessary to form the author's view on the definition of the category "model of economic behavior" for the construction of applied models of behavior of economic entities. The author interprets the model of economic behavior of enterprises as a generalized description of the economic behavior of enterprises through a system of relevant logic (and/or mathematical) dependencies that reflect the nature and essence of economic activity as a consequence of the mutual influence of relevant 
determinants. This interpretation is a synthesis of previously presented research to determine the category of "model of economic behavior," the model of economy essence as a conditional image, economy, built to facilitate its research [1] in the context of impersonation of an enterprise with micro model of the economy and own view on the nature of the process under study.

Obviously, the functioning of enterprises according to the appropriate model of economic behavior is aimed at a certain development. As stated [2], the development of enterprises suggests the following options: internal growth through the use of private resources; mergers, acquisitions as a means of increasing resources; reallocation of internal resources, focusing them on priority areas; cessation of low priority activities resourced through sale of shares and assets or the elimination of internal liquidation - re-orientation; separation, transfer of activities not supported by resources, other performers on a contractual basis, through the sale or allocation of assets.

However, according to the author, the basis of any vector of development is the desire to survive (save itself, have a certain stability) and the desire to develop (self-improvement). The dominance of certain areas of development can be shown [3, p. 126] in the appropriate development strategy: orientation to capital accumulation or long term presence on the market; or in the crisis: exit strategies (on the basis of which measures are taken to minimize losses in the result of a quick exit from the business), strategy of compression (limiting compression of business with the aim of preserving the resources in the post-crisis period can "open up" like a spring and push the company forward and turn the stored energy of compression in competitive advantage), strategy of expansion (purchase of assets of the companies which fell sharply or for their development or for subsequent sale at more favorable market conditions). At the same time, the implementation of the selected trajectories and development strategies is provided by the appropriate model of economic behavior of the enterprise.

Problems of different types of models of economic behavior of domestic enterprises are noted in the research of several modern scientists.

Thus, studying strategies of management of the enterprise in the conditions of emergency activity, O. Miklukha focused special attention [4, p. 187] on the strategic behavior of the enterprise and the choice of a strategic model of behavior of the enterprise in certain conditions. Accordingly, the proposed algorithm for choosing a strategic model of enterprise behavior in emergency conditions has variations between the conservative and active model. The conservative model ensures the preservation of economic ties, old structure and range of products, reducing the volume of economic activity (reduction of employees, repairs on their own, lower wages) and the collapse of investment projects. The active model requires the search for opportunities to establish new economic ties, develop new design solutions, attract investment funds, changes in the organizational structure of the enterprise, changes in the range and structure of output and payroll depending on the results of activity [4, p.188]. It should be noted that the identical division of models of economic behavior of enterprises into active, mixed and conservative are proposed by N. Biloshkurska [5], but according to the criterion of readiness for adaptation.

On the basis of more detailed applied results in the context of a sample study of the behavior of economic entities, pace and mechanisms of their adaptation to market conditions $\mathrm{H}$. Kaplenko proposed to distinguish three models of economic behavior of enterprises: destructive, constructive and mixed These models are characterized as a whole by a set of actions and activities that are associated with search, creation, preservation, expansion and use of places of application of efforts, relevant sources of income generation and distribution, or vice versa with the restriction and drawdown of market activity [6, p. 11].

Thorough applied research by T. Dolgopiatova [7, p. 29] on the basis of empirical data determined the allocation of three models of behavior of enterprises: close to pre-reform, market and mixed. However, it is worth noting that such a classification raises, as we have personally seen, a number of questions, which indicates a certain limitation of it. After all, the proposed approach provides an opportunity to generalize all the variety of phenomena and processes, taking into account the process of transformation of the economic system from administrative to market, while in practice there are such phenomena and processes that are difficult to uniquely assess as market or fundamentally new, given the individual dogmas of economic theory. At the same time, the value of this approach, and especially the exclusive empirical data that really covered the features of the transformation of enterprises in the post-Soviet territory and a number of conclusions drawn at the same time, is undeniable.

Thus, T. Dolgopiatova notes that the dominant model of economic behavior of enterprises is survival, which is inherent in these models of behavior [7]. The priority of security is manifested in an attempt to preserve traditional economic relations and find ways to incorporate them into new ones. According to a particular model, the main direction of behavior of enterprises - preservation of its integrity, including personnel, control of management, key relationships with contractors, traditional sources of development and activities [7, p. 32]. In particular, unique (belong to certain enterprises in accordance with the market situation - monopoly, high scarcity, etc.) and typical (available to most enterprises) models of survival are highlighted.

Agreeing with the adequacy of the above models of economic behavior of enterprises in the interpretation of $\mathrm{O}$. Miklukha, H. Kaplenko, T. Dolgopiatova, it is worth noting that their allocation was rather fractional than complex, that is, individual, different aspects of management were analyzed without trying to create a general picture of events and situation. Thus, O. Miklukha chose a business strategy as the basis of models classification, H. Kaplenko - mechanism of adaptation to market conditions, T. Dolgopiatova - the transformation of conditions of management, $\mathrm{N}$. Biloshkurska - the willingness to adapt. 
In contrast to the presented results, focusing on the features of the functioning of domestic industrial enterprises, that is, real processes, we believe that the basis of their behavior is the chosen direction of activity: production, mixed (a combination of production, financial, investment activities), rent-oriented, which should provide socially productive activities [8]. Therefore, we distinguish three models: 1) model of production-oriented behavior; 2) model of mixed behavior; 3) model of rent-oriented behavior. These models in content do not contradict the above and, rather, logically include such, because, acting in market or close to market (mixed) conditions, each of three models can be conservative or active; destructive, constructive or mixed.

We are convinced that the priority for industrial, in particular, machine-building enterprises should be their industrial development, which, as noted by O. Kuzmin [9, p. 80], is a diverse process of changing processes and technology, improving on this basis the organization of production units, production processes, improving (but, it is not excluded, and deterioration) of the economic performance of the enterprise. This is laid down by the author in the model of economic behavior of the enterprise. The model of mixed economic behavior is characterized by a combination of industrial development with other activities (leasing, financial transactions, investment activities, etc.). The model of rent-oriented behavior is a reflection of the lack of production development, entrepreneurial principles based on ensuring socially productive activities and meeting the self-interests of the most powerful agents without any benefit to the enterprise.

For the purpose of more in-depth disclosure of certain models of economic behavior of the enterprise we consider it necessary to characterize them from the position of synthesis of types of economic behavior.

Table-I: Characteristics of models of economic behavior of the enterprise

\begin{tabular}{|c|c|c|c|c|}
\hline \multirow{2}{*}{\multicolumn{3}{|c|}{\begin{tabular}{l|l}
$\begin{array}{l}\text { Description; } \\
\text { feature of } \\
\text { types classifications }\end{array}$ & $\begin{array}{l}\text { Model of } \\
\text { production-oriented } \\
\text { behavior }\end{array}$ \\
\multicolumn{2}{l|}{ The concept of economic behavior model }
\end{tabular}}} & $\begin{array}{l}\text { Model of } \\
\text { mixed } \\
\text { behavior }\end{array}$ & $\begin{array}{l}\text { Model of } \\
\text { rent-oriented } \\
\text { behavior }\end{array}$ \\
\hline & & & \multicolumn{2}{|c|}{ 1. The concept of economic behavior model } \\
\hline \multicolumn{2}{|l|}{ General description } & $\begin{array}{l}\rightarrow \text { production } \\
\rightarrow \text { development: } \\
\text { improvement } \\
\text { equipment, } \\
\text { technologies, } \\
\text { organization of } \\
\text { production units }\end{array}$ & $\begin{array}{l}\cap \text { production } \\
\text { development with } \\
\text { financial and } \\
\text { investment } \\
\text { activity }\end{array}$ & $\begin{array}{l}\text { lack of productive } \\
\text { development } \\
\text { entrepreneurial activity } \\
\text { in connection with } \\
\text { socially productive } \\
\text { activity }\end{array}$ \\
\hline \multicolumn{5}{|c|}{ 2. Interrelation of models of economic behavior of the enterprise } \\
\hline \multirow{3}{*}{$\begin{array}{l}\text { Models of economic } \\
\text { behavior of the } \\
\text { enterprise by } \\
\text { O. Miklukha and } \\
\text { N. Biloshkurska }\end{array}$} & Active & + & & \\
\hline & Mixed & + & + & \\
\hline & Conservative & + & + & + \\
\hline \multirow{3}{*}{$\begin{array}{l}\text { Models of economic } \\
\text { behavior of the } \\
\text { enterprise by } \\
\text { H. Kaplenko }\end{array}$} & Destructive & + & + & + \\
\hline & Constructive & + & + & \\
\hline & Mixed & + & + & \\
\hline \multirow{3}{*}{$\begin{array}{l}\text { Models of economic } \\
\text { behavior of the } \\
\text { enterprise by } \\
\text { T. Dolgopiatova }\end{array}$} & Close to reform & + & + & \\
\hline & Market & + & & \\
\hline & Mixed & + & + & \\
\hline
\end{tabular}

The given characteristic shows the potential multiplicity of combinations in a separate model of economic behavior. The model of rent-oriented behavior is mainly characterized by pessimistic, non-market, non-strategic, anti-social, financial direction of the enterprise functioning and generalizes conservative and destructive models of behavior. In addition, we believe that this model of behavior may be inherent in enterprises that survive or exist inert in an oligopoly, passively waiting for or ignoring changes.

On the other hand, models of production-oriented and mixed behavior in general have a similar overall potential for choosing a relatively optimistic, stabilizing, pessimistic direction of action; market, non-market orientation; strategic, non-strategic direction; socially responsible, socially-oriented, anti-social activities; reactive, proactive behavior or ignoring changes. At the same time it concerns the nature of actions: struggle, waiting, improvement, security; type of market form: in conditions of pure monopoly, in conditions of monopolistic competition, in conditions of oligopoly, in conditions of pure competition; degree of reaction to changes: reactive, proactive, ignoring changes; state and conditions of development: growth, 
security, inert existence, stability and survival. In addition, the model of production-oriented behavior can be saturated with a sufficiently large variability of behavior models on other grounds: active, mixed, conservative; destructive, constructive, mixed; close to the reform, market, mixed. With respect to the mixed economic behavior model, it almost corresponds to the saturation of combinations of the production-oriented behavior model with the exception of the active and market behavior model.

So, we believe that the main conclusion of the above is the key statement that the effectiveness of the chosen model (production-oriented and mixed) depends primarily on the correct combination of directed efforts. It should also be noted that there is a difference on priorities, the functional elements in the aforementioned two models: if production-oriented model is a major industrial and innovative activity, the model of mixed behaviour is observed accentuation on the economic (or more complex) feasibility of a combination of financial, marketing, sales, production operations. At the same time, we would like to emphasize the fact that there is a potential filling of each model with formal and informal behavior; risky and non-physical activity; deviant, opportunistic, delictual and criminal behavior. Although the level of deviance, risk, rules of conduct depend on the consistency of internal and external agents of the enterprise.

We will assess the economic behavior of enterprises according to the author's methodology of interpreting models of economic behavior of enterprises [8] and analyze them in the context of the selected models of economic behavior of the above-mentioned scientists. Financial and economic activity of 22 machine-building enterprises for 2002-2018 was chosen as objects of research [10,11]. The analysis revealed that among studied companies 9 companies operate on a model of rent-oriented behavior, namely: Dashivskyi repair-mechanical plant PJSC, Vinnytsia plant "Budmash" PJSC, Vinnitsa's researching factory PJSC, Mogyliv-Podilskyi Engineering Plant PJSC, Voronovytsia specialized enterprise "Agromash" PJSC, Ulaniv "Agromash" PJSC, Trostianet district enterprise "Agromash" PJSC, Shargorod district enterprise "Agromash" PJSC, Agromashkomplekt PJSC. This illustrates that enterprises either re-oriented their main activity other than mechanical engineering (out of the industry) or lease premises. Consequently, this model of behavior is uniquely destructive and conservative and is the basis for effective development and decline. We will assess the enterprises of production-oriented and mixed industry and consider the prospects of development.

Table-II: Assessment of models of economic behavior of enterprises

\begin{tabular}{|c|c|c|}
\hline Enterprise & $\begin{array}{l}\text { Model of economic behavior of } \\
\text { enterprises in } 2018\end{array}$ & $\begin{array}{l}\text { Characteristics of model of } \\
\text { economic behavior }\end{array}$ \\
\hline $\begin{array}{l}\text { 1. Ladyzhyn repair and mechanical } \\
\text { plant PJSC (Ladyzhyn city) }\end{array}$ & $\begin{array}{l}\mathrm{y}=-0,0009 \mathrm{x} 2+0,6516 \mathrm{x}-16,905 \\
\mathrm{R}^{2}=0,7826 \\
\text { mixed economic behavior }\end{array}$ & $\begin{array}{l}\text { Mixed, constructive, mixed } \\
\text { (close to reform/market) }\end{array}$ \\
\hline $\begin{array}{l}\text { 2. Bar machine-building plant PJSC } \\
\text { (Bar city) }\end{array}$ & $\begin{array}{l}\mathrm{y}=-4 \mathrm{E}-05 \mathrm{x} 2+1,1194 \mathrm{x}-202,42 \\
\mathrm{R}^{2}=0,6866 \\
\text { mixed economic behavior }\end{array}$ & Mixed, constructive, market \\
\hline $\begin{array}{l}\text { 3. Kalynivka machine-building plant } \\
\text { PJSC } \\
\text { (Kalynivka city) }\end{array}$ & $\begin{array}{l}\mathrm{y}=-4 \mathrm{E}-05 \mathrm{x} 2+1,0354 \mathrm{x}-442,94 \\
\mathrm{R}^{2}=0,6065 \\
\text { mixed economic behavior }\end{array}$ & Mixed, constructive, market \\
\hline $\begin{array}{l}\text { 4. Kalynivka district enterprise } \\
\text { "Agromash" PJSC (Kalynivka city) }\end{array}$ & $\begin{array}{l}\mathrm{y}=7 \mathrm{E}-05 \mathrm{x} 2+0,5299 \mathrm{x}-89,897 \\
\mathrm{R}^{2}=0,6561 \\
\text { mixed economic behavior }\end{array}$ & $\begin{array}{l}\text { Conservative, destructive, } \\
\text { mixed (close to reform/ market) }\end{array}$ \\
\hline $\begin{array}{l}\text { 5. Kalnyk Specialized Enterprise } \\
\text { "Agromash" PJSC } \\
\text { (Kalnyk village, Illinetsky district) }\end{array}$ & $\begin{array}{l}\mathrm{y}=-0,0073 \times 2-0,3858 \mathrm{x}-3,1517 \\
\mathrm{R}^{2}=0,6135 \\
\text { mixed economic behavior }\end{array}$ & $\begin{array}{l}\text { Conservative, destructive, } \\
\text { mixed (close to reform/ market) }\end{array}$ \\
\hline $\begin{array}{l}\text { 6. Komsomolske } \quad \text { Specialized } \\
\text { Enterprise "Agromash" PJSC } \\
\text { (Komsomolske village, Kozatynsky } \\
\text { district) }\end{array}$ & $\begin{array}{l}\mathrm{y} \quad=\quad 1,1004 \mathrm{x}-1 \\
\mathrm{R}^{2}=0,8668 \\
\text { production-oriented economic behavior }\end{array}$ & istructive, market \\
\hline $\begin{array}{l}\text { 7. Mogyliv-Podilskyi gas equipment } \\
\text { and devices plant } \\
\text { (Mogyliv-Podilskyi) }\end{array}$ & $\begin{array}{l}\mathrm{y} \quad=\quad 0,9669 \mathrm{x}-1 \\
\mathrm{R}^{2}=0,9051 \\
\text { production-oriented economic behavior }\end{array}$ & $\begin{array}{l}\text { Conservative, destructive, } \\
\text { mixed (close to reform/ market) }\end{array}$ \\
\hline $\begin{array}{l}\text { 8. Vinnytsiaavtospecobladnannia PJSC } \\
\text { (Vinnytsia city) }\end{array}$ & $\begin{array}{l}\mathrm{y}=0,0002 \mathrm{x} 2+0,6916 \mathrm{x}-8,4476 \\
\mathrm{R}^{2}=0,6523 \\
\text { mixed economic behavior }\end{array}$ & $\begin{array}{l}\text { Conservative, destructive, } \\
\text { mixed (close to reform/ market) }\end{array}$ \\
\hline
\end{tabular}




\begin{tabular}{|c|c|c|}
\hline $\begin{array}{l}\text { 9. Yampil instrument-making plant } \\
\text { PJSC } \\
\text { (Yampil city) }\end{array}$ & $\begin{array}{l}\mathrm{y} \quad=\quad 1,017 \mathrm{x} \quad- \\
\mathrm{R}^{2}=0,9935 \\
\text { production-oriented economic behavior }\end{array}$ & Active, constructive, market \\
\hline $\begin{array}{l}\text { 10. Vinnytsia plant "Mayak" PJSC } \\
\text { (Vinnytsia city) }\end{array}$ & $\begin{array}{l}\mathrm{y}=-4 \mathrm{E}-05 \mathrm{x} 2+1,7558 \mathrm{x}+1425,4 \\
\mathrm{R}^{2}=0,7171 \\
\text { mixed economic behavior }\end{array}$ & $\begin{array}{l}\text { Mixed, constructive, mixed } \\
\text { (close to reform/ market) }\end{array}$ \\
\hline $\begin{array}{l}\text { 11. Bershad electrotechnical plant PJSC } \\
\text { (Bershad city) }\end{array}$ & $\begin{array}{l}\mathrm{y} \quad=\quad 1,0277 \mathrm{x} \quad- \\
\mathrm{R}^{2}=0,9983 \\
\text { production-oriented economic behavior }\end{array}$ & Active, constructive, market \\
\hline $\begin{array}{l}\text { 12. Enterprise "Medtekhnika" PJSC } \\
\text { (Vinnytsia city) }\end{array}$ & $\begin{array}{l}\mathrm{y}=-0,0003 \mathrm{x} 2+0,7619 \mathrm{x}+75,328 \\
\mathrm{R}^{2}=0,8161 \\
\text { mixed economic behavior }\end{array}$ & $\begin{array}{l}\text { Mixed, constructive, mixed } \\
\text { (close to reform/ market) }\end{array}$ \\
\hline $\begin{array}{l}\text { 13. Vinnytsia enterprise "Remprylad" } \\
\text { PJSC } \\
\text { (Vinnytsia city) }\end{array}$ & $\begin{array}{l}\mathrm{y}=0,001 \times 2-0,4288 \mathrm{x}+7,1421 \\
\mathrm{R}^{2}=0,569 \\
\text { mixed economic behavior }\end{array}$ & $\begin{array}{l}\text { Conservative, destructive, } \\
\text { mixed (close to reform/ market) }\end{array}$ \\
\hline
\end{tabular}

Note: $\mathrm{x}-$ financial result from the main activity, thousand UAH;

$\mathrm{y}$ - financial result before tax, thousand $\mathrm{UAH}$; $\mathrm{R} 2$ - coefficient of determination.

\section{RESULT AND DISCUSSION}

The results of the study show that among 13 enterprises only 4 enterprises operate on the model of production-oriented behavior, including 3 enterprises are characterized by active, constructive and market behavior. It is advisable to indicate this in view of the fact that these enterprises receive a positive financial result, which tends to increase. In particular, Mogyliv-Podilskyi gas equipment and devices plant PJSC, which operates on the model of production-oriented behavior, is characterized by conservative, destructive and mixed. This is a reflection of inefficient development, which has contributed to negative financial results in recent years. With regard to enterprises engaged in economic activity on a mixed model of behavior, it is advisable to note that only 3 enterprises (Ladyzhyn repair and mechanical plant PJSC, Vinnytsia plant "Mayak" PJSC and Enterprise "Medtekhnika" PJSC) are characterized by constructive and close to market behavior. This is an indication that these enterprises are mainly engaged in production activities in combination with other activities have positive financial results. The remaining 6 enterprises, which operate on a mixed model of behavior, are characterized by conservative, destructive and close to reform behavior and is evidence of inefficient development of all activities, including production. Consequently, this demonstrates the need for fundamental changes in their production activities to ensure the effective development and success of all activities.

\section{CONCLUSION}

The theoretical and methodological and applied research proves that there is a number of variations of models of economic behavior of enterprises, which are interchanged by the corresponding set of features. However, the most methodically defined, which are possible for use as analytical tools, are the proposed models of production-oriented, mixed and rent-oriented behavior of enterprises. Regarding the future prospects of research, we consider it necessary to expand the methodological tools for assessing the activities and development of enterprises from the standpoint of models of their economic behavior.

\section{REFERENCES}

1. 1. Kyrylenko, V.V. (2002), Ekonomika [Economics], Naukova dumka, Ternopil, Ukraine.

2. Totsky, V.I. and Lavrinenko, V.V. (2005), Orhanizatsijnyj rozvytok pidpryiemstva [Organizational development of the enterprise], Naukova dumka, Kyiv, Ukraine.

3. Savinova, O.M. and Kasianova, N.V. (2005), "The concept of increasing economic potential is a way to develop machine-building enterprises in the region under the latest conditions", Menedzher, vol. 3, pp. 121-127.

4. Miklukha, O.L. (2004), "Modeling strategy management in an emergency activities", Visnyk Ukrains'koho derzhavnoho universytetu vodnoho hospodarstva ta pryrodokorystuvannia. Ekonomika. Zbirnyk naukovykh prats', vol. 11, pp. 185-190.

5. Beloshkurskaya, N.V. (2010), "Adaptive behavior models and their role in formation of enterprise economic security", Aktual'ni problemy ekonomiky, vol. 12, pp. 101-105.

6. Kaplenko, G.V. (2005), "Formation of economic behaviour of the enterprises", Ph.D. of Science (Economics) Thesis, Economy, organization and management, Institute of regional research NAS of Ukraine, Lviv, Ukraine.

7. Dolgopyatova, T. (1999), "State-owned enterprises: a model transformation", Voprosy jekonomiki, vol. 2, pp. 27-36.

8. Moroz, O.V. Karachyna, N.P. and Ostryi, I. F. (2017), "Contemporary and perspective researches of enterprises economic behavior”, Ekonomika ta derzhava, vol. 4, pp. $16-20$.

9. Kuzmin, O. and Alexeyev, I. (2002), "Problems of enterprise development research", Rehional'na ekonomika, vol. 1, pp. 75-82.

10. State Statistics Service of Ukraine (2019), available at: http://www.ukrstat. gov.ua. (Accessed 25 September 2011). 
11. Smida (2019), "Financial statements of enterprises", available at: http://www.smida.gov.ua (Accessed 25 September 2011)

\section{AUTHORS PROFILE}

Karachyna N.P. graduated from Vinnitsa National Technical University with a degree in management in the production sphere, received a diploma of specialist in economics, as a production manager, during 2000-2019 engaged in teaching activities at the Vinnitsa National Technical University.

Scientific interests: corporate governance, economic behavior of the enterprise, models of economic behavior of enterprises, economic security.

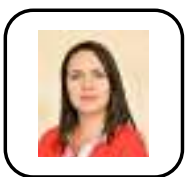

Samofalova M.O. graduated from Vinnitsa National Technical University with a degree in Management of Organizations, received a Master of Management Degree in Corporate Governance, during 2007-2019 is engaged in teaching activities, in 2018 has joined the National University of Life and Environmental Sciences of Ukraine and is currently working.

Scientific interests: risk-management of enterprise personnel, non-standard methods of personnel management.

Bilyak Y.V. graduated from the National Aviation University with a degree in Management of Foreign Economic Activity of the Enterprise, received a Master\&apos;s Degree in Management of Foreign Economic Activity of the Enterprise, during 2003-2019 is engaged in teaching activities, in 2012 has joined the National University of Life and Environmental Sciences of Ukraine and is currently working.

Scientific interests: financial consequences of conflicts in agrarian sector of Ukrainian economy.

Drahnieva N.I. - graduated from the National Agrarian University with a degree in management of the organization, received a diploma as a specialist in economics and law, during 2007-2019 is engaged in teaching activities at the National University of Life and Environmental Sciences of Ukraine.

Scientific interests: quality management, personnel management. 